\title{
Pensar el miedo. Mitos, arte y política ${ }^{1}$
}

\section{Think fear. Myths, art and politics}

Silvia N. Barei

\section{Resumen}

Este trabajo se pregunta acerca del miedo como construcción cultural y como estrategia de los poderes. La aparición de ciertos sujetos vinculados al miedo sostiene parte del entramado de nuestras sociedades violentas, la incertidumbre, lo que puede ocurrir como tremendo o como desmesurado. Las amenazas imaginarias se vuelven reales y las amenazas reales se exacerban en el imaginario social. ¿Qué miedos tienen hoy y en su vida cotidiana, los hombres y mujeres del mundo occidental? Al terrorismo, al cambio climático, a los inmigrantes, a lo que se denomina «inseguridad», al mal uso de la tecnología, a la fragilidad de los sistemas políticos y económicos. A la fragilidad de la democracia. Cada grupo, cada país, pone el acento en alguno de ellos. América Latina no se priva de ninguno de estos miedos. Ejemplificando con textos de la cultura latinoamericana tratamos de entender cómo funciona el miedo, por qué se exacerba en determinados momentos históricos, en qué mitologías y tradiciones se ampara, cuáles son sus políticas y cómo se expresa en cierto tipo de textos artísticos.

Palabras clave: Culturas del miedo; Vida cotidiana; Políticas; Textos artísticos

\begin{abstract}
This work addresses fear as a cultural construction and as a strategy of power. The appearance of certain subjects linked to fear sustains part of the network of our violent societies, uncertainty, what can be perceived as tremendous or as excessive. Imaginary threats become real and real threats are exacerbated in the social imaginary. What fears do men and women of the western world have nowadays in their daily lives? They fear terrorism, climate change, immigrants, also what is called «insecurity», the misuse of technology, the fragility of political and economic systems. The fragility of democracy. Each group, each country, puts the accent on any of them. Latin America is not deprived of any of these fears. Exemplifying texts from Latin American culture, we try to understand how fear works, why it is exacerbated in certain historical moments, in what mythologies and traditions it is protected, what its policies are and how it is expressed in certain types of artistic texts.
\end{abstract}

Keywords: Cultures of fear; Everyday life; Politics; Artistic texts

\footnotetext{
${ }^{1}$ Trabajo recibido el 30/05/2019. Aceptado el 24/07/2019.

${ }^{2}$ Universidad Nacional de Córdoba. Contacto: sbareiberrueta@gmail.com
} 
Los sentimientos para nosotros corresponden al espacio de las emociones estandarizadas en un preciso momento histórico. Mientras que los afectos y las emociones se sitúan en el espacio menos aceptado por las normas y por ello poseen un status de mayor libertad.

Adriana Boria (2018)

\section{Política y emociones: el miedo}

Me manda un mensaje un colega que sabe que estoy reflexionando acerca del miedo. El mensaje sostiene que el miedo es atávico, instintivo y lo justifica con esta cita puesta en boca de un personaje de una serie televisiva:

Antes de conocerte era una mujer civilizada. Civilizada. Ahora ni siquiera sé qué significa eso. Comida, casa y sexo, una vez que estas necesidades están cubiertas, podemos fingir que tenemos el control. Que las vidas que hemos construido nos hacen humanos. ¿Sabes cómo lo sé? Miedo...El miedo es lo que nos convierte en animales (Apple Tree Yard, Temporada 1, Episodio 1).

Si la cultura nos hace humanos, también es cierto que poseemos una reacción instintiva, un miedo innato se podría decir, que es parte constitutiva de nuestro ser animal y que desde tiempos inmemoriales ha servido para protegernos. Si me gritan o me tocan un bocinazo, me asusto y seguramente evito un grave riesgo.

Pero no es este el miedo que interesa pensar acá, sino el miedo que aprendemos, el que le permite a la sociedad mantenerme a raya, ubicarme en un lugar, un rol, un papel, el miedo que me separa de otros, el que no me deja asumir la propia sexualidad o elección de género, el miedo a estar en el lugar del diferente. Lo que Eric Fromm llama «el miedo a la libertad»; un miedo aprendido y condicionado por cada cultura.

El miedo nos pone en el lugar de la víctima o del victimario. Pero en los dos lugares alternativamente. Nos dejamos agredir, maltratar, subestimar por miedo. Agredimos, maltratamos y subestimamos por miedo. Uno podría dar muchísimos ejemplos y no haría falta hablar de otros. Nosotros mismos somos siempre un buen ejemplo. El miedo acecha a la vuelta de la esquina rosada para decirlo con Borges. Y a la vuelta de muchos trabajos y muchas posiciones sociales: los docentes, los médi- 
cos, los abogados, los periodistas, los políticos, por nombrar sólo algunos que conozco de cerca, somos profesionales del miedo. Para qué hablar de los curas, los curanderos, las adivinas, los policías y los gendarmes. Lo peor de todo es que este miedo se inculca para hacernos supuestamente un bien.

Tenemos como buen ejemplo cómo se construyó en la Edad Media el miedo a las brujas, creando una paranoia colectiva de delación, traiciones y oportunismos, canalizados magistralmente por la Iglesia y por la Justicia. Unos vieron en las mujeres estigmatizadas como «brujas» una vasta conspiración contra la iglesia, otros una conspiración contra el Estado (Juana de Arco fue quemada como bruja), otros un desafío a la ciencia racional y recién nacida. Toda una conjunción de creencias e imaginarios propios de sociedades que «habían permanecido largo tiempo en el estadio mágico» (Delumeau, 2017, p. 463).

Este es un tipo de miedo que muestra claramente el rol de la mujer en esta época, la imposibilidad de aceptar que no estuviera sujeta al poder del hombre, que pensara por sí misma o que ejerciera una profesión.

En su estudio sobre la caza de brujas, Iuri Lotman (2008) ubica claramente esta persecución como parte de circunstancias históricas y culturales:

el aumento del miedo contribuyó al éxito de la imprenta, que otorgó a la literatura demonológica una envergadura sin precedentes, así como la influencia de Oriente, el papel del descubrimiento de América y otras causas que hicieron que los miedos que se incubaban en la época medieval estallasen en miles de hogueras durante la época más 'ilustrada' del Renacimiento y el Barroco, en vísperas del siglo de la Razón (p.13)

La persecución contra las mujeres tiene una larga data. Hipatia, la única mujer científica en la biblioteca de Alejandría, fue muerta por una turba enloquecida. ¿Quién era y qué hacía Hipatia?

La bella y sabia Hipatia fue la primera mujer del mundo occidental en ocupar el último cargo de secretaria de la gran Biblioteca de Alejandría antes del incendio... Hipatia dictaba allí clases sobe Platón (Requena, 2009, p. 24). 
El asesinato, acto supuestamente justiciero, restaura un equilibrio, sostiene el orden social. En un mundo dominado por hombres, una mujer sola, matemática, y filosofa es una amenaza. La turba que irrumpe en la biblioteca está enajenada socialmente y por supuesto, alentada en su violencia por una alienación religiosa. Esta enajenación es la estructura misma de toda sociedad regida por una férrea división de castas, de clases, de profesiones, de edades y de género en culturas desiguales donde los sujetos se creen a merced de los dioses, dependientes de los poderosos y parte de un sistema social donde no se sabe si se ha de vivir mañana. La violencia contra el otro -sea quien sea, niño, mujer, extranjero- se nutre del miedo. Un miedo que no crece naturalmente sino que se multiplica en el contexto cultural y se sustenta en el respaldo de la historia.

El miedo a la mujer sabia es el mismo que opera en relación con la bruja ya que, entendemos con Lotman (2008) que «detrás de tales acusaciones asoma claramente el miedo de la mayoría masculina a perder su situación de dominio en la sociedad» (p. 30)

Porque todo miedo tiene una historia y una prehistoria. $\mathrm{Y}$ tal vez en el fondo, un mito. ¿Acaso Antígona no tiene miedo? Sí, lo tiene. Pero está constreñida por la paradoja que implican dos mandatos sociales diferentes: obedecer la obligación ancestral de enterrar a los propios muertos y desobedecer el mandato social de su tiempo, de no enterrar a los traidores. Respetar a los dioses, desconocer a Creonte, rey de Tebas, que ha prohibido el entierro de su hermano Polinices.

Antígona levanta su mano contra el poder porque ello significa no sólo reparar una ofensa sino restaurar el equilibrio de un mundo que no puede pensarse fuera del otro: el mundo del más allá. Aunque en apariencia sus actos no tienen un claro sentido político, la reparación de una injusticia en una sociedad violenta es el trasfondo de todo su hacer. Vivir significa para ella cumplir con un ritual necesario. Sin este ritual no hay vida trascendente para el muerto. Pero en esta particular circunstancia personal e histórica, vivir significa también desobedecer. Conservar la dignidad y perder la vida. Al final, ella también será el otro, el muerto. La muerta, sujeto de la violencia del poder.

Enajenados por los mandatos de los poderosos, los sujetos son derrotados por el miedo. Pero no solo por el suyo propio, sino por el de todos los que pertenecen a su misma cultura. Aprenden a no cuestionar, a aceptar las reglas impuestas, a no indagar sobre las causas o sobre su legitimidad porque esta actitud es garantía de supervivencia, de estabilidad. Es el precio que se paga por el pacto que le propone la sociedad del 
«orden»: previene de la exclusión, cohesiona a todos, es el modo de pertenecer a un lugar seguro de la propia cultura. La obediencia baliza el miedo, asegura el contacto con los demás, garantiza no ser ultrajado. Y muchas veces ser notablemente reconocido.

En la novela de Jorge Accame Forastero (2009), un pueblo entero está sometido al silencio y a la dominación ejercida por el dueño de la finca en la que todos directa o indirectamente trabajan. Un periodista, el forastero, investiga la desaparición de muchas mujeres y la respuesta que obtiene es del orden del mito: el ingenio está custodiado por el «familiar». Como una protagonista de la novela lo dice, todo ocurre,

al revés que Antígona... Antígona cubrió de tierra el cuerpo de su hermano muerto para cumplir con las leyes divinas, pese a que el Estado se lo había prohibido. Ella en cambio desenterró un cadáver buscando exponer el crimen a los ojos de todos (p. 79)

El miedo cierra la boca del pueblo y la violencia atraviesa toda la trama inscripta en la historia de la dominación y las deudas sociales renovadamente impagas en el tiempo. Ya no hay reyes, pero siguen existiendo los «patrones» en una provincia donde todos callan y solo los que vienen de afuera asisten a «una historia larga de sometimiento» (p. 104). Alguien le dice al forastero: «a veces viene algún entrometido como usted a perturbar el antiguo equilibrio que nos esforzamos en mantener» (p. 104).

Es notable cómo literatura y mito se imbrican para dar cuenta de un estado del mundo que, en su aparente «racionalidad» sigue dominado por una violencia que se ejerce sobre todos, viola las reglas, adapta las leyes para sí y nunca teme autodestruirse.

Sin mito, sin magia, sin brujería, los seres humanos no llegan a torcer el destino, esa otra fuerza que aparece como límite de su propia humanidad. Este parece ser el mensaje de la última novela de Claudia Piñeiro (2017), Las maldiciones.

Una maldición de la historia argentina cae sobre los personajes: ningún gobernador de la provincia de Buenos Aires, llegará a ser presidente de la República. Como en el libro de Accame, acá también una periodista investiga esta maldición, esta fuerza mítica, y viene a dar con un ambicioso político empeñado en romperla. Para ello, cuenta con la ayuda de la brujería -que esconde prolijamente- y de sus seguidores a los que engaña a diario con un discurso -ahora le llamamos fake Newsque la novela desnuda en su cálculo individual de costos y beneficios. 
El entrecruzamiento de historia, mito y mentiras crea acontecimientos, impone un orden a una multitud de actos, premoniciones y vaticinios y denuncia el modo que la mala política usa para llegar al poder.

Pero, ¿qué es una maldición? Es la expresión de un deseo negativo que se logra mediante el poder mágico del lenguaje. De raigambre mítica y religiosa, la primera maldición en la tradición judeo-cristiana la pronunció Dios contra la serpiente, y luego contra el hombre y la mujer expulsándolos del paraíso. En la tradición griega, y ya que hablamos de Antígona, toda la descendencia de Edipo es víctima de un destino adverso manifestado en la capacidad profética de la palabra: «Tu linaje se exterminará a sí mismo».

De hecho, la maldición tiene un vínculo emocional con un comportamiento supersticioso y aparece a contrapelo de toda mentalidad racional. Fernando Rovira (tal el nombre del político protagonista de la novela) puede planear fríamente destinos para los otros y para sí mismo, pero la maldición terminará alcanzándolo. Su vida cotidiana es una puesta en escena a través de un ejercicio de manipulación sustentado en el miedo. El personaje oculta, insulta, domina, desprecia, impone. Y si es necesario, mata.

La presencia del amor (de otro personaje hacia su hijo) permite rehacer el futuro, enmarcar al mito en tanto residuo nocivo y situar al presente como lugar donde la víctima puede vencer el miedo que lo paraliza y es capaz de torcer su destino a pesar de las lenguas que lo maldicen (y los sicarios que lo persiguen). Juega el juego del otro y lo atrapa en su propia telaraña.

La lógica víctima-victimario a la que nos referíamos, habita la lógica social y la lógica política. Ambas son inseparables y se necesitan porque reproducen las relaciones de desigualdad. Y es el discurso social el mecanismo que sostiene esa reproducción. Rovira inventa una versión propia y conveniente de su historia. Una versión »melosa, cursi, que empalaga al tercer párrafo», pero que convence a sus votantes. Esgrime un discurso que ha venido en llamarse en nuestros días la posverdad.

$\mathrm{O}$, en otras palabras, lo que esta misma expresión oculta: el travestismo de la verdad, la mentira contada como cierta. 


\section{The truth is gone}

En el año 1969, el grupo de rock The Good Rats grabó la canción The truth is gone, compuesta por el líder de la banda Pepsi Marchello.

Por entonces, la teoría social comenzaba a abordar la noción de verdad entendiéndola como una construcción discursiva, históricamente marcada, e instalaba en el campo de las Ciencias Sociales la discusión acerca del relativismo de ciertas verdades que se construyen por medio de la manipulación del discurso.

Pero ya no estamos en los revolucionarios años 60 . Y la verdad se ha convertido en posverdad.

El siglo XXI nació, para la historia, el 11 de septiembre de 2001, mojón inicial para la «guerra contra el terrorismo» que permite a Estados Unidos atacar e intervenir en países que cree potencialmente peligrosos: Afganistán, Irak, Irán, Libia, Siria.

La posverdad nace por entonces, casi diríamos el día que George Bush decidió no creer a los veedores internacionales y afirmar que Irak tenía armas nucleares para justificar la invasión (marzo de 2003) Estos hechos que se inscriben en el larguísimo periplo histórico de enfrentamientos entre Oriente y Occidente, tienen como respuesta en los años siguientes, los atentados perpetrados por grupos radicalizados como el Estado islámico. Después de Nueva York, Londres, Madrid, Paris, Niza, Estocolmo, Bruselas, Marsella, estos ataques han generado nuevos miedos, nuevas xenofobias y nuevas formas del cinismo.

Antes de los ataques del 11 de septiembre Bin Laden dijo: «iTengan miedo!». Y después se instauró el terror a sufrir un atentado, «un nuevo miedo», que afecta la vida diaria de muchos sujetos en el planeta.

También el siglo XXI ha sido denominado «la era de la información», facilitada por una tecnología que permite no solo formas de comunicación impensadas anteriormente, sino por programas de vigilancia electrónica en todo el mundo. Algo que ni siquiera Orwell había llegado a imaginar. Por ello, tenemos miedo hoy a los usos y abusos de la tecnología en manos de los poderes. Miedo a los ataques cibernéticos. Miedo a que nos roben nuestros datos, nuestra identidad, nuestra magra cuenta bancaria.

A la luz de todos estos hechos complejos, en un mundo complejo, aparece la posverdad profundamente relacionada con los nuevos miedos. El Diccionario de Oxford eligió en 2017 a la palabra posverdad como la palabra del año: se afirman como verdaderas cosas falsas y cualquiera 
sabe hoy que Donald Trump es su máximo referente. Y los medios de comunicación y las redes sociales sus difusores más importantes. En Estados Unidos, en Rusia, en Brasil y en la Argentina de hoy también se manipula el discurso, se miente y se lesionan profundamente los lazos sociales. ¿qué es hoy la verdad? Es una mentira contada por Donald Trump. O por Temer. O por Macri. O por Bolsonaro. O por la ultraderecha sueca, alemana o húngara.

Sabemos que hacen pasar gato por liebre, que la verdad que se enuncia es un artificio para justificar actos privados y públicos cuyas formas y consecuencias pueden afectarnos terriblemente. Y esto genera miedos. Pero, ¿qué miedos tienen hoy los hombres y mujeres del mundo occidental? A los atentados, al cambio climático, a los inmigrantes, a lo que se denomina «inseguridad», al mal uso de la tecnología, a la fragilidad de los sistemas políticos y económicos. A la fragilidad de la democracia. Cada grupo, cada país, pone el acento en alguno de ellos. América Latina no se priva de ninguno.

Para los griegos, nos recuerda Hannah Arendt (2014), la esperanza y el temor eran pasiones «malas». Tanto una como otra no alcanzan para ver la realidad tal cual es; una la idealiza, el otro la rehúye. Pero ambos son ineludibles. Son parte de nuestros sentimientos, de nuestra «afectuosa» naturaleza humana. La esperanza produce discursos idealistas y hasta utópicos y el miedo lleva al mutismo. De allí las expresiones «me paralicé de miedo», «me quedé duro del susto», «me quedé mudo» o, como dicen graciosamente los mexicanos, «me apaniqué».

América Latina es un continente atravesado históricamente por las políticas del terror. Y estas marcas se llevan en la piel y en la conciencia. Fray Bartolomé de las Casas necesitó acompañar s u Brevisima relación de la destrucción de las Indias, (1542) con dibujos espantosos de hombres y mujeres torturados, vejados, castigados, mutilados, asesinados, comidos por perros, quemados, descuartizados y cuantos horrores uno pueda imaginarse, para que los pocos letrados de su época y las grandes masas de iletrados comprendieran lo que es ahora, verdad de perogrullo: que los nativos eran también humanos y que los poderes (iglesia y monarquía) actuaban de manera criminal.

Su libro cuestiona la legitimidad de la conquista (hoy la llamamos más apropiadamente, invasión) y defiende la humanidad de los indios como seres portadores de razón y con derecho a la libertad. Algo así como un defensor de los derechos humanos más de dos siglos antes de la Revolución Francesa. 
Hasta hoy, uno escucha en muchas aldeas americanas de fuerte componente indígena, invocar familiarmente la protección del «padrecito de las Casas». Porque el Estado no protege y porque las políticas de seguridad también dan miedo. Montan una escena criminal difusa, incierta y con rostros desconocidos. Quien puede espiarnos, quien puede amenazarnos y quien puede asaltarnos no tiene rostro.

En la Argentina actual, se espía hasta a aquellos que no deberían ser espiados, sino protegidos. Por ejemplo, las mujeres de los submarinistas desaparecidos en el episodio del Ara San Juan, la familia de Santiago Maldonado o los ciudadanos que denuncian la complicidad policial con la droga y el delito. Y lo que se llama «inseguridad» (se puede ser asaltado, violado, asesinado a cualquier hora del día y en cualquier lugar), se ha vuelto una emoción colectiva que se hace visible a través de informaciones y de imágenes.

Estos miedos construyen parte del entramado de nuestras sociedades violentas, de la incertidumbre, de lo que puede ocurrir como tremendo o como desmesurado. Amenazas imaginarias que se vuelven reales y amenazas reales que se exacerban en el imaginario. Creación y aparición de sujetos portadores de miedo. Configuraciones imaginarias que hacen del otro un amigo o un enemigo. Estereotipos y construcciones que se leen en los diarios, pero que están concretamente representados cada vez que encendemos un televisor para ver un Noticiero o buscamos en Internet el nombre de la última mujer o niña asesinada.

Hablando de la violencia expuesta en los medios, María José Mondzain (2016) subraya «la exhibición y la difusión sin límites de los gestos más salvajes frente a un público horrorizado y fascinado a la vez» (p.122).

Los miedos tienen una pasión melodramática que yo llamaría «fundante» si no fuera porque este adjetivo remite a un origen nunca comprobable. Pero puedo imaginar a un pequeño grupo de homínidos, reunidos en una cueva protectora, a la luz de un fuego mantenido siempre vivo para evitar el ataque de las bestias. Puedo escuchar entonces, al joven cazador relatando más con gestos y sonidos guturales que con palabras, su enfrentamiento con un tigre dientes de sable. ¿Qué otros hombres habrán querido estar en su lugar, que mujeres lo habrán admirado, qué niños se habrán imaginado ser como él?, ¿Qué miedos les causaría un mundo hostil y desconocido y su vulnerabilidad a diario manifiesta?, ¿Qué estructura de sentimientos, que ahora llamaríamos atávica, funda 
este relato?, ¿Y sigue sirviendo obviamente, a los personajes que propagan el miedo en la actualidad?

No habría miedos si el miedo no fuera también necesario a las sociedades. Para su supervivencia y para su amordazamiento, el miedo es un instrumento cultural.

\section{Tiempos de oscuridad}

En sus estremecedoras biografías de Hombres en tiempos de oscuridad, señala Hannah Arendt (2014) que

La historia conoce muchos períodos de tiempos de oscuridad en los que el ámbito político quedó ensombrecido y el mundo se tornó tan dudoso que la gente dejó de pedirle a la política otra cosa que no fuera demostrar la debida consideración por sus intereses vitales y la libertad personal (p. 24)

Arendt habla de tiempos en que el mundo era un campo de batalla y los sujetos considerados diferentes, el otro (cualquier otro) tensaba las cuerdas de una tolerancia que nadie estaba dispuesto a soportar. La cita se resignifica en estos tiempos en que el ejercicio del poder en muchos países latinoamericanos persigue a quienes cuestionan las decisiones de lo que se quiere imponer más allá de toda situación de vulnerabilidad.

La apertura hacia los demás es una condición de humanidad. Sabemos que nos volvimos humanos mucho antes de hablar, cuando aparecieron las primeras formas de socialización, de relaciones interpersonales afectivas estrechas, la recolección de alimentos, la caza, la protección de las crías, el gesticular y el reír juntos. Dato notable este último. Aristóteles ya señalaba que el hombre es el único animal que ríe. Y es también un animal político, es decir, ejerce deberes y derechos como ciudadano en la polis. Pero si tiene miedo no puede ejercerlos.

«Las imposibilidades lingüísticas», como les llamó Kafka, son las imposibilidades de hablar y también de escuchar al otro, o si se lo escucha, creer que está equivocado, que no es capaz de entender los signos de los nuevos tiempos. Como una falta de ortografía en las palabras que la calle escribe.

En casi toda América Latina (creo que Bolivia era la excepción 
más honrosa) la sociedad tal como está no se puede sostener sobre la base de la inequidad y la injusticia. En esto consiste la más profunda inhumanidad de las clases gobernantes. La ambición, la soberbia, el autismo, imponen la idea de que los errores fueron cometidos antes y por otros. Una verdad que no se discute y con la que tenemos que sufrir, un imperativo categórico y absoluto sin cuya corrección, nunca seremos felices. El complejo de superioridad nos hace inhumanos.

Pero la desesperación personal que impulsa casi a diario en Argentina, a tanta gente a la calle, esa salida fuera de las ilusiones y los papelitos de colores, esa conciencia de estar escuchando una verdad disfrazada, por lo tanto, irritante y ofensiva, proviene de que en un mundo hostil los dueños del poder no están interesados en el bienestar de nadie, menos aún en transformar el sufrimiento de muchos.

Con otras características, de manera más engañosa y brutal, esto pasa también en Brasil. La gente no ha salido a la calle por un tarifazo ni por la falta de trabajo, ni por la expoliación a los jubilados o las clases obreras. Ha salido frente a la brutalidad del poder, la militarización de las favelas, el asesinato de Marielle Franco (14 de marzo de 2018); ha salido para cuestionar la condena sin pruebas a Lula da Silva, ha salido para decir «Ele nao, ele nunca» a Bolsonaro.

Favorito para volver a ser presidente de Brasil en las elecciones de octubre de 2018, Lula se refugió la noche del 5 de abril en el Sindicato Metalúrgico de San Pablo, lugar que lo vio nacer a la política sindical. Espacio y lenguaje, ya lo sabemos, definen a las culturas.

«Ya no soy un ser humano. Soy una idea», señaló Lula, claro en su auto conciencia de estar perdiendo peso humano y creciendo en el imaginario de un pueblo. ${ }^{3}$ ¿Puede una idea, un hombre estigmatizado por unos y convertido en mito de talla latinoamericana por muchos, enfrentarse al miedo que impone el poder? 'Tiene el poder miedo a Lula?

Efectivamente, Lula es un miedo nombrado. Es decir, tiene nombre, apellido, persecuciones y coraje propios. Tan seguro está él mismo de que le tienen miedo y de que por eso necesitan mantenerlo entre rejas, que en el último discurso dijo: «este cuello aquí no se baja... yo no estoy escondido, voy a ir hasta sus narices para que sepan que no tengo miedo, que no voy a correr». ${ }^{4}$

\footnotetext{
${ }^{3}$ Veáse la nota del diario El Pais, «Ya no soy un ser humano, sino una idea». Disponible en: https://sso.elpais.com.uy/cas/login? showAs= paywall\&service $=$ https $\% 3 \mathrm{~A} \% 2 \mathrm{~F} \% 2 \mathrm{~F}$ www.elpais.com.uy\%2Fcas-check\&utm_source=article

${ }^{4}$ Veáse la nota del diario El Pais, «Ya no soy un ser humano, sino una idea». Disponible en:
} 
Con Lula libre, el miedo cobra una dimensión política, amenaza por la simple razón de que existe. Lula preso sirve para mostrar la fuerza y el control, para conjurar el horror a la inversión de las jerarquías sociales, para conservar el monopolio de los instrumentos de violencia, para garantizar la eficacia de una justicia para pocos.

Diría Marc Auge (2014): «La República pierde pie en cuanto ya no se comprende como un equilibrio pacificado entre los diferentes miedos que la dividen» (p.45).

Tanto con Lula preso o libre, el miedo cobra una dimensión política en el sentido más amplio que los griegos dieron a la palabra: afecta de manera directa la vida de los ciudadanos en la polis.

\section{Bandidos y raperos}

Iniciado el nuevo siglo, en el 2001, León Gieco editó un álbum titulado Bandidos rurales dedicado a aquellos personajes populares declarados «enemigos públicos» y que tuvieron en vilo por muchos años a la policía. Juan Moreira, Vairoletto, Mate Cocido, Hormiga negra, pusieron sus vidas al servicio de la pasión, el heroísmo, la injusticia y tuvieron un final doloroso y violento. Quedaron como héroes populares, como mitos que guarda la memoria colectiva y León los define como «Bandidos rurales, difícil de atraparles/ igual que alambrar estrellas en tierra de nadie».

Una década antes, en las periferias de la Argentina Primer mundo del menemismo, había surgido la cumbia villera, un subgénero de la cumbia latinoamericana, cantada por bandas cuyos nombres son significativos: Yerba brava, Pibes chorros, Mala fama.

Esta cumbia aparece como expresión cultural de sectores vulnerables en las villas de Buenos Aires y los personajes de las letras encarnan una apología de los excesos de una clase social marginal y marginada con vidas atrapadas por el delito y el paco. Sus letras son testimoniales y contestatarias, no ofrecen salida, no rompen estereotipos, son machistas y violentas y hacen gala de una escenificación de lo real, exhibida como forma de vida:

https://sso.elpais.com.uy/cas/login? showAs= paywall\&service $=$ https $\% 3 \mathrm{~A} \% 2 \mathrm{~F} \% 2 \mathrm{~F}$ www.elpais.com.uy\%2Fcas-check\&utm_source = article 
Lloren violines que hoy ninguno queda vivo le vamos a dar faca y faca vamos a caerle a ese Gil le vamos a dar faca y faca vamos a podrirla hasta morir (Faca y faca)

Tumberos, Ya no llores, Los dueños del pabellón, Sos un botón, La canción del yuta dicen cosas que estaban en las páginas policiales de los diarios, pero no estaban hasta ese momento, en la estética de la cumbia o de la canción popular. Los héroes no son bandidos rurales, son pandilleros y asesinos, miembros de tribus urbanas, sometidos a ritos de iniciación y lenguaje tumbero que sobreviven en territorios marginales como la villa o hacinados en las cárceles desde donde siguen manejando sus redes reverenciales al culto del jefe, el amo, el más fuerte, el más duro.

En el año 2007, viví por unos meses en Hermosillo, Estado de Sonora, zona «caliente» del México norteño, lugar central de la narcocultura. Llamó mucho mi atención que la noche anterior a mi llegada, en un baile, había sido asesinado el cantante de una banda de narcocorridos, Sergio Gómez, y me sacudió aún más, que unos días antes de mi partida, asesinaran a Zayda Peña, cantante de otro grupo. En 2006 habían matado a Valentín Elizalde y a Javier Morales Gómez cuyos nexos con los narcos eran ampliamente conocidos y cuyas canciones eran escritas a pedido de los propios jefes de la droga. Hasta la actualidad estas muertes son en México moneda corriente. Los enfrentamientos entre los cárteles se llevan también la vida de aquellos vinculados a cantantes y compositores y a quienes ni sus vidas de artistas populares, alcanzan a salvar.

Así como la cumbia villera es una variante de la cumbia colombiana, los narcocorridos son una variante del corrido mexicano nacido durante la Revolución. El corrido narra historias de valientes, perseguidos, pistoleros y caballos, con una percepción heroica del mundo, ligada a la muerte, la lucha por un ideal y el goce de la vida. Bandidos rurales también, pero mexicanos.

Con el correr de los años la Revolución se institucionaliza y ya en la década del 30 aparece la cultura de la droga y los primeros narcocorridos. Sin embargo, es en los 60, cuando toman la forma en que los conocemos ahora y surgen las bandas que en poco tiempo se harán famosas: Los tigres del norte, Los Broncos de Reynosa, Los Tucanes de Tijuana. En vez de héroes revolucionarios, villistas o zapatistas, ensalzan las hazañas y vi- 
das de traficantes famosos. El Chapo Guzmán, El Mayo Zambada, Pablo Escobar ya habían impuesto un gusto estético que, más allá de la música y la ropa, instala una cultura compleja. Al decir de Carlos Monsiváis, una cultura que exhibe «el demasiado dinero, lo brillante, lo ostentoso, como signos de distinción».

Los jefes de los cárteles se imponen a la vez como sujetos cuyas vidas se imitan desde el «dudoso prestigio de lo ilegal», tal como señala Enrique Flores (2013):

La narcocultura amplió su radio de influencia a través de los narcocorridos, muchas veces pagados por los mismos protagonistas. En la confusión ambiente, los trovadores vinculados al crimen gozan del dudoso prestigio de lo ilegal que se somete a la moral del pueblo...Aunque suene curioso o divertido o folklórico, cantar las peripecias de quienes venden yerbamala al otro lado, los narcocorridos pertenecen a un sector que causa decenas de asesinatos al día ( $\mathrm{p}$. 22)

Como nota para una historia del rock argentino, se puede recordar que los Redonditos, en el álbum Luzbelito, incorporan un tema que se llama Me matan, Limón, célebre frase última del también célebre Pablo Escobar.

Este ejemplo cercano da cuenta del «aura» de personajes ligados al narco, con su proyección en distintos países latinoamericanos, que en Colombia dio origen al corrido prohibido y que, en el México más actual y ligado a la cultura del hip hop y del gangster rap americano, ha dado surgimiento a la estética de lo que se conoce como narco rap

El narco rap tiene su anclaje en la música nacida hacia fines de los 70 y años 80 en los barrios negros de Nueva York, asociado a la cultura del hip-hop, es decir de un conjunto de formas artísticas callejeras entre las cuales el rap (del acrónimo Rhythm and Poetry), exhibe su cuerpo en la vereda, sus golpes rítmicos y sus muletillas verbales.

Con aportes de ritmos populares, rituales africanos y sones jamaiquinos, el rap elabora textos casi fonológicos cuyas letras hablan de violencia, pobreza, machismo, exclusión, marginalidad y lucha anti-sistema.

En el caso del narco rap mexicano, se trata de una nueva generación de cantantes y compositores (¿habría que llamarlos Milennials?), reciente producto de la narcocultura, entre los que se destacan $E l$ cártel de Santa, Cano \& Blunt y Makiabelico. Estos jóvenes son herederos de 
los «viejos» narcocorridistas y de ellos dijo un periodista: «Estos chavalones, ya no son esos viejones a los que les gustaban los corridos».

Los narco-raperos «chavalones», componen y cantan para los jefes y sicarios de los cárteles con quienes están vinculados y exhiben esta pertenencia desembozadamente. Como el rap americano, la palabra expresada tiene un contenido fuerte y expresivo y la aliteración y la rima simple son fundamentales para facilitar no solo la sonoridad sino, al modo de las antiguas baladas, romances y cantares, la memorización para su expresión oral.

Soy del grupo de los Zetas

que cuidamos al patrón

somos veinte de la escolta

pura lealtad y valor (Escolta suicida)

Somos puro Reynosa

un chingo de malandros

pura gente mafiosa

lo sufres o lo gozas

(Reynosa la Maldosa)

En el México norteño, ser artista y ser narco parecen, en muchos casos, las dos caras de una misma moneda. Una cara que supera largamente a los románticos bandidos rurales de las culturas campesinas o apenas urbanizadas en Latinoamérica. Los nuevos narco raperos son verdugos y víctimas, al tiempo que expresan una estética de pandilla y la violencia entroniza a los siempre triunfantes «señores de la guerra», dueños del miedo:

El es El 3

señor de respeto

también conocido como El Metro.

Le han querido dar pa abajo

eso es muy cierto,

los que lo intentaron han quedado en el concreto.

La gente controla,

a poco no lo ven;

todo controlado por el Comandante 3. 


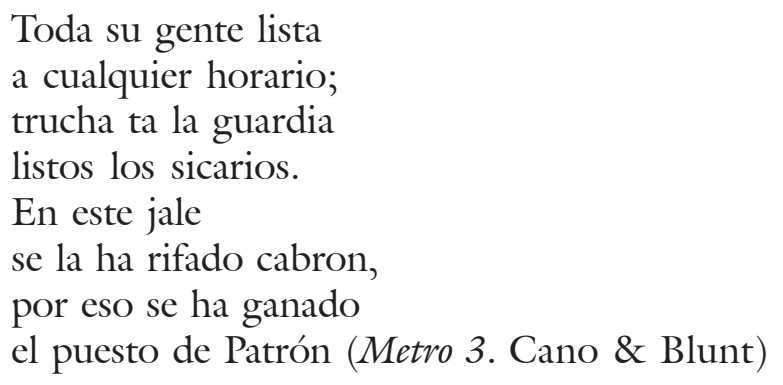

A tal punto es cierto que los nuevos raperos son verdugos y víctimas que en Mexico sorprenderia poco una información aparecida el sábado 28 de abril vinculada con la desaparición de tres estudiantes universitarios:

un rapero de 24 años, que también tiene un canal en YouTube con más de un millón de visitas, fue el responsable de quemar con ácido los cuerpos de los tres estudiantes mejicanos de cine que trabajaban en un proyecto escolar en Guadalajara, cuando fueron secuestrados por una banda narco ${ }^{5}$

Utilizar una pistola, utilizar el lenguaje o las redes sociales, poner el cuerpo en un escenario, en el mundo virtual o marchar a una cárcel, se despliegan sobre un fondo simbólico donde el mito liga a los personajes a través de la canción: revolucionarios, bandidos, villistas, corridistas, narcos famosos, raperos o narco raperos son parte de un simbolismo transgresor que la cultura de masas y más actualmente, la cultura virtual, pone en escena, consume, usa en publicidad y marketing y finalmente, amenaza, mata y olvida.

\section{Algo que debería ser un cierre y no lo es}

La cultura del miedo es entonces parte de nuestra vida cotidiana desde épocas prehistóricas. Los ejemplos que hemos utilizado sirven para mostrar cómo el miedo nos acecha a diario y sus signos son legibles en la política, el arte y las informaciones cotidianas. El miedo nos hace víctimas o victimarios, por ello en la novela Los tigres de la memoria Juan

\footnotetext{
${ }^{5}$ La Voz del Interior, 28/04/2018.
} 
Carlos Martelli (1997) pone en boca de un personaje amenazado por las fuerzas policiales, esta frase que parece atávica: «Ser el diablo es salvarse del diablo. Producir miedo es salvarse del miedo. Salvarse del miedo es el secreto de la vida» (p. 65).

¿El miedo es un sentimiento, una emoción, un afecto? Creo que el epígrafe que cita a Adriana Boria pone claro sobre oscuro. Al menos, sobre grises.

El miedo es al tiempo una emoción, una reacción compleja ante un estímulo -ya sea externo (me gritan) o interno (recuerdo cuando alguien me amenazaba) - y un sentimiento, o sea, una emoción de la que se toma conciencia.

En tanto sentimiento, entendemos nuestros miedos y podemos entender los de los demás: qué los han generado, qué nos amenaza individual y colectivamente, cómo hemos reaccionado, qué podemos hacer. En un preciso momento histórico, dice Boria (2018), ha sido el punto en que hemos situado el interés de este trabajo: la construcción cultural y social de los miedos.

Esta gramática histórica es la que permite reflexionar sobre el miedo y describirlo, tratar de entender el momento estratégico y el valor sígnico de su emergencia.

No creemos que las mujeres que investigan en un laboratorio hagan brujerías, sin embargo, seguimos escuchando decir: «esta noche salgo con la bruja»; no creemos que la democracia sea un sistema que deba amenazar a sus pueblos, sin embargo, hemos oído decir a un presidente: «Si me pongo loco, puedo hacerles mucho daño»; no creemos que un proyecto económico-político deba beneficiar a unos pocos, supo ello un diario de nuestros días, refiriéndose a esto titula: «El presupuesto del miedo»; entendemos que los pueblos amenazados en su integridad física y en sus necesidades económicas deban emigrar masivamente. La fuerza representada por estas imágenes es inmensa. Y signo y significación se multiplican según el cristal con que se mire.

El miedo es parte de nuestros sentimientos y de nuestras construcciones culturales. Nunca nos libraremos de él, como no nos libraremos, por suerte, del amor o de la solidaridad. Solo tratamos de saber cómo funciona, por qué se exacerba en determinados momentos históricos, en qué mitologías y tradiciones se ampara, cuáles son sus políticas y cuál su posibilidad de sentar verdades (o posverdades), cómo se expresa en el texto artístico, cómo deviene muchas veces un espectáculo doloroso 
y excesivo del sufrimiento de otros, una forma de mirar al otro como portador de inhumanidad y de desorden.

Pareciera que el miedo ayuda también a prevenir, a curar, a vivir más fácilmente, aunque los modos del conjuro sean muchas veces ciegos o brutales y solo piense en los atributos de las víctimas, no en su humanidad, sino en su forma de mostrarla. Joven: peligroso; motociclista: motochorro; villero: narco; artista: subversivo; pobre: ladrón; mujer y militante: abortista; cura: violador; viejo: ignorante, y así seguimos sin parar, como el signo ad Infinitum de Peirce. De este modo, el otro incrementa nuestros miedos. Y fue así antes, ahora y parece que el futuro no augura mejoras.

Eduardo Galeano (2005) nos traza genialmente este «Mapa del miedo»:

Hace unos cuatrocientos cincuenta mil años, la mujer y el hombre frotaron dos piedras y encendieron el primer fuego, que los ayudó a pelear contra el miedo y el frío.

Hace unos trescientos mil años, la mujer y el hombre se dijeron las primeras palabras, y creyeron que podían entenderse.

Y en eso estamos todavía: queriendo ser dos, muertos de frío, muertos de miedo, buscando palabras (p. 119).

\section{Bibliografía}

Accame, J. (2009). Forastero. Buenos Aires, Argentina: Sudamericana. Arendt, H. (2012). Hombres en tiempos de oscuridad. Barcelona, España: Gedisa.

Auge, M. (2014). Los muevos miedos. Buenos Aires, Argentina: Paidos.

Boria, A. (2018). Sujetos del exceso: emociones e identidades sociales. Inédito.

Boucheron, P. y Corey, R. (2016). El miedo. Buenos Aires, Capital intelectual.

Delumeau, J. (2017). El miedo en Occidente. Madrid, España: Taurus.

Doughty, L. (2017). Apple Tree Yard [serie de televisión]. Inglaterra: BBC One.

Galeano, E. (2005). Bocas del tiempo. Buenos Aires, Argentina: Sudamericana. 
Flores, E. (2013). Rimas malandras. México, México: UNAM.

Lotman, Iuri (2008). Caza de brujas. La semiótica del miedo. Revista de Occidente, (329), 10-33.

Martelli, J. (1997). Los tigres de la memoria. Buenos Aires, Argentina: Sudamericana.

Mondzain, M. J. (2016). ¿Pueden matar las imágenes? Buenos Aires, Argentina: Capital Intelectual.

Piñeiro, C. (2017). Las maldiciones. Buenos Aires, Argentina: Sudamericana.

Requena, J. (2009). Hipatia o la muerte del amor. Córdoba, Argentina: Intempo. 